\title{
Epidemiological Profile of Violence against the Elderly in the State of Minas Gerais, Brazil
}

\author{
Gabriela Fernandes de Oliveira ${ }^{a}$, Breno Resende Rodrigues da Cunha ${ }^{\text {a }}$, \\ Anderson de Cintra Souza a, Mariana Giorgiani a , Juliana Rizza Ribeiro Batista a , \\ Paula Monikee Rezende Alves a, Maria Tereza Néri Rosa ${ }^{a}$, Stefan Vilges de Oliveira ${ }^{a^{*}}$ \\ ${ }^{a}$ Department of Collective Health, Faculty of Medicine, Federal University of Uberlândia, Uberlândia, Minas Gerais, Brazil. \\ Received 06 April 2019; Accepted 25 May 2019
}

\begin{abstract}
Purpose: The main objective of the present study is to evaluate the violence against the elderly population of the Minas Gerais state, between 2007 and 2017, in order to draw an epidemiologic profile of these events through the gathering of secondary data registered by the Information System for Notifiable Diseases (SINAN). Methods: We analyzed data from the public health system between 2007 and 2017, in order to draw an epidemiologic profile of these events through the gathering of secondary data registered by the Information System for Notifiable Diseases (SINAN). The acts of violence committed were classified according to the injured body part, the number of people involved, the sex of the victim, suspect of alcohol abuse by the aggressor, the race, the marital status, the location, the aggressor's gender, the relationship with the victim and the evolution to death. Results: By analyzing this data, it was possible to notice 15086 notifications of violence against the elderly in 814 cities of the Minas Gerais state, and 122 of those cities had cases that resulted in deaths. Conclusion: Hence, it was possible to conclude that several aspects exist in this kind of violence, such as the victim's gender, the type of violence, the number of aggressors, relationship, and others still. Thereby, this study highlights the need of more research on this topic, in order to offer better combat against this type of violent actions, since the increase of the elderly population is due to Brazil's demographic transition that has been occurring in the last years.
\end{abstract}

Keywords: Epidemiology; Violence; Elderly; Brazil; Minas Gerais.

\section{Introduction}

According to the World Health Organization (WHO), the increasing longevity is one of the main achievements of humanity but is also one of its biggest challenges [1]. Many countries have been , or will be, through a demographic transition period. This is characterized by the decreasing of birth and death rates and the increasing of population aging is a consequence of the young people decrease in these countries [2].

In Brazil, this demographic transition began in 1970, when the country's population profile changed from a predominantly rural and traditional society, with large families, to an urban one, with lower fecundity rates and new familiar structures. For this reason, we can see an increasing number of people aged 60 years or more [1].

This extension in life expectancy has the consequence of increasing the Brazilian population morbidity, which is proportional to the growth of incapacitation diseases. These disorders, in addition to cause life risk for elderly people, are a potential threat to their independence and autonomy [1].

\footnotetext{
* Corresponding author: stefan@ufu.br

do) http://dx.doi.org/10.28991/SciMedJ-2019-0102-1

$>$ This is an open access article under the CC-BY license (https://creativecommons.org/licenses/by/4.0/).

(C) Authors retain all copyrights.
} 
Besides, the recent population aging in Brazil has happened in a fast and irregular way. Added to the context of static or declining resources and the increasingly social inequality, we have public institutions poorly equipped to meet the growing demand of the aging population [3].

In addition, the violence against this group reached huge proportions, what it has been an alarming epidemiologic fact for the Brazilian population, demanding a larger investigation about this issue. WHO [4] defines violence against the elderly as an act committed or omitted, resulting from an intentional or voluntary behavior. The abusive act can be of a physical or psychological nature and it may involve material or financial maltreatment.

All kind of abuse will result in unnecessary suffering, injury, damage or pain, loss or violation of human rights and a significant decrease in life quality for the elderly. Queiroz [5] describes some characteristics that are considered risk factors for this kind of violence, such as weakening of the familial bonds, isolation, and deception of the caregiver, elevated dependence and unproductivity of the elderly, cultural and socioeconomic factors and general stress at the care.

In this scenario, it's important to remember that Brazil has policies made to protect the aged who suffers all kind of violence. One exempla is the Law number 8842/94 [6] that sets the National Politics of the Elderly and creates the National Council of the Elderly, which main goal is to assure the social rights, integrate the elderly in society and promote their autonomy. Beyond that, the decree number 1948/96 [7] regulates this law and assigns the competences that private and public institutions must follow to assure the care and treatment of the elderly. Besides, in 2003 the Senior Citizens' Statute was created by the Law number 10741 [8].

This way, all violence against the elderly must be notified to the Ministry of Health that establishes public politics of Surveillance and Attention to the Health of this population [9]. Moreover, the violence cases must be notified at the Information System for Notifiable Diseases (SINAN) of the Brazilian Ministry of Health [10]. These methods are strategies for epidemiologic surveillance, with the intention to recognize the profile of the aggressions and propose public politics of prevention and control of these events.

The recognition of the epidemiologic profile is a predecessor strategy to reduce the aggression cases in the population, and these analyses must be routinely done at all the different levels of Brazil's Unified Public Health System (SUS) activities. For this reason, this study has as the main goal to evaluate the violence against the elderly in Minas Gerais state, trying to establish an epidemiologic profile of these events.

\section{Research Methodology}

A descriptive study was done, with secondary data from Minas Gerais State's SINAM, from January 2007 until December 2017. Minas Gerais is a state from Brazil's southeast region, with 853 municipalities, and has Belo Horizonte as its capital (Figure 2-A) [11]. According to the last Brazilian Institute of Geography and Statistics (IBGE) data gathering, made in 2017, it has $586520.732 \mathrm{~km}^{2}$ of territorial area, making it the fourth biggest Brazilian state. In 2010, 19597330 people were registered, being $11.8 \%$ of them with 60 or more years, and 0.731 of HDI, placing Minas Gerais as the ninth in Brazil's human development ranking [12].

The inclusion criteria were the data registered in SINAN from January 2007 until December 2017, belonging to the elderly population (60 or more years) of the Minas Gerais state. The notification forms that were incomplete, unrelated to the elderly or from other states were excluded.

This study considered as elderly population the definition from the first article of the Brazilian Law number $10.741 / 2003$. It is enacted the Statute of the Elderly, in order to regulate the ensured rights of the people with age of 60 (sixty) or more years [8].

The following variables were analyzed: Age range, the gender of the victim and of the aggressor (male, female or ignored), relationship with the victim (father, mother, other relatives, friend/neighbor, stranger, caregiver, others or ignored), alcohol abuse by the aggressor (yes, no or ignored), type of violence suffered (physical, psychological, sexual or others), marital status of the victim (single, married, widow/widower, divorced or does not apply), race (as defined by the IBGE: white, black, yellow, multiracial, indigenous or ignored), body part injured (head/face, neck, teeth/mouth, spine/marrow, chest/back, abdomen, hip/pelvis, upper limbs, lower limbs, genital organs/anus, multiple organs/regions, does not apply), place where the aggression occurred (street, avenue, house), number of involved (one, two or more, or ignored).

For the data extraction from the SINAN platform, the production of the maps according to the municipality of violence occurrence and deaths, Tabwin 3.2, a program provided by the Brazilian Health Ministry was utilized. Thereafter, Microsoft Office Excel 2016 was used to make the sheets. Thenceforth, the data was statistically descriptive analyzed using frequency measures. 
The incidence coefficients of the cases of violence against the elderly were calculated according to the municipality of occurrence, and the year of the study presented based on the notified cases. In order to analyze the incidence, data from the population estimates from the IBGE [13]. To calculate the average incidence coefficients, the arithmetic mean of the respective years was used.

It is important to highlight that all the ethical, and legal aspects were respected. However, it is not necessary to subject to Ethics Committee, since the data analyzed in the project were extracted from the non-nominal secondary data platform, of the Brazilian Health Ministry, that all citizens have free access.

\section{Results}

From the performed data analysis, was possible to perceive that 15086 violence against the elderly notifications cases occurred in the state of Minas Gerais. Thus, a mean incidence of 30.64 cases per 100000 inhabitants was noted. From these notification, 194 cases led to death in consequence of the violence (Figure 1).

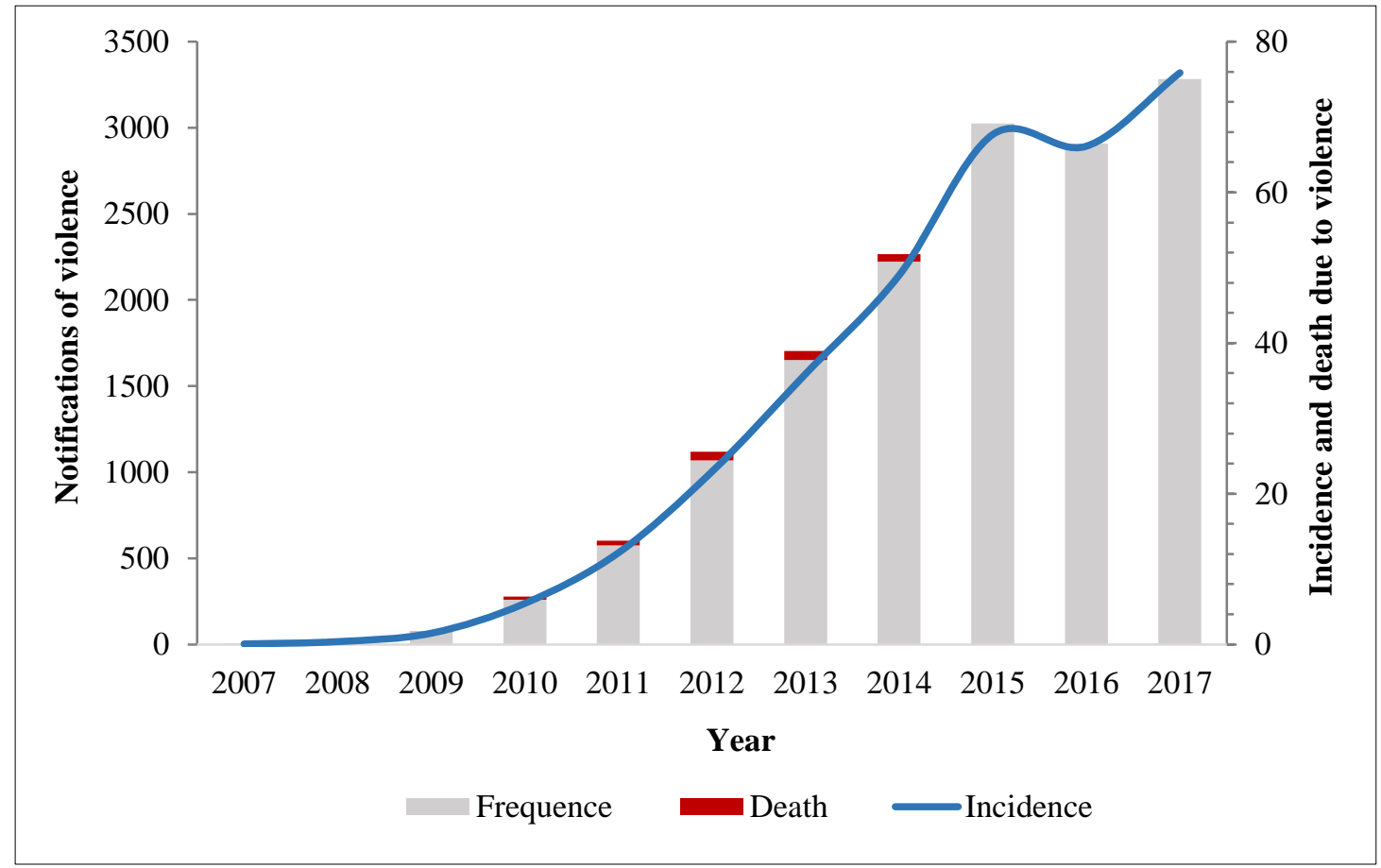

Figure 1. Number of notifications, incidence, and number of deaths, by violence against the elderly, registered in the state of Minas Gerais between 2007 and 2017

Violence against the elderly cases were registered in 814 municipalities of the state of Minas Gerais, ranging from 1 case (minimum) to 1136 cases (maximum) per municipality. On the other hand, deaths secondary to violence against the elderly were registered in 122 municipalities of the state, ranging from one death (minimum) to ten (maximum) deaths per municipality, as shown by Figure 2.
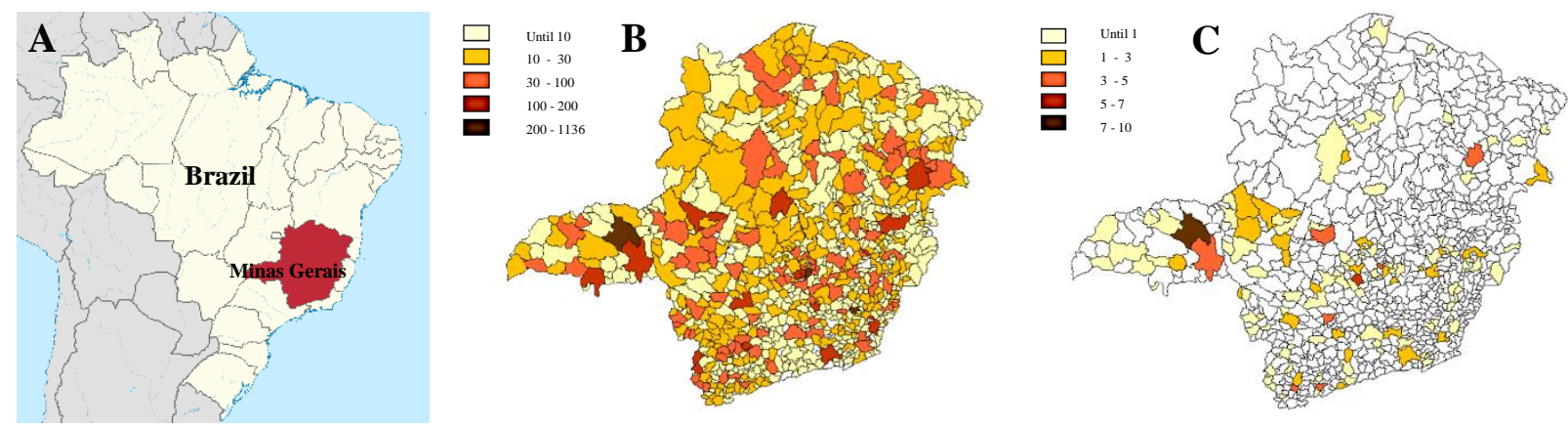

Figure 2. A. Geographic location of Brazil and the state of Minas Gerais. B. Spatial distribution of violence against the elderly cases according to the city of occurrence in Minas Gerais. C. Spatial distribution of deaths as a result of violence against the elderly according to the municipality of occurrence in Minas Gerais 
By classifying the carried out acts of violence in relation to the body parts mostly affected, is perceived that more than one quarter of the lesions were directed to the face/head, followed by superior limbs, that correspond to $19.69 \%$ of the cases, as shown by Figures 3 and Table 4.

Furthermore, the data point to the fact that the majority of aggressions are made by only one subject (60.46\%). An important result is that $54.38 \%$ of the aggressions are directed against elderly women, but $71.05 \%$ of the cases that culminate in death are directed against men. Another relevant factor is that $28.6 \%$ of the occurrences happened with the aggressor under suspicion of alcohol use, pointing to the fact that the substance is also related to those violence cases (Table 1).

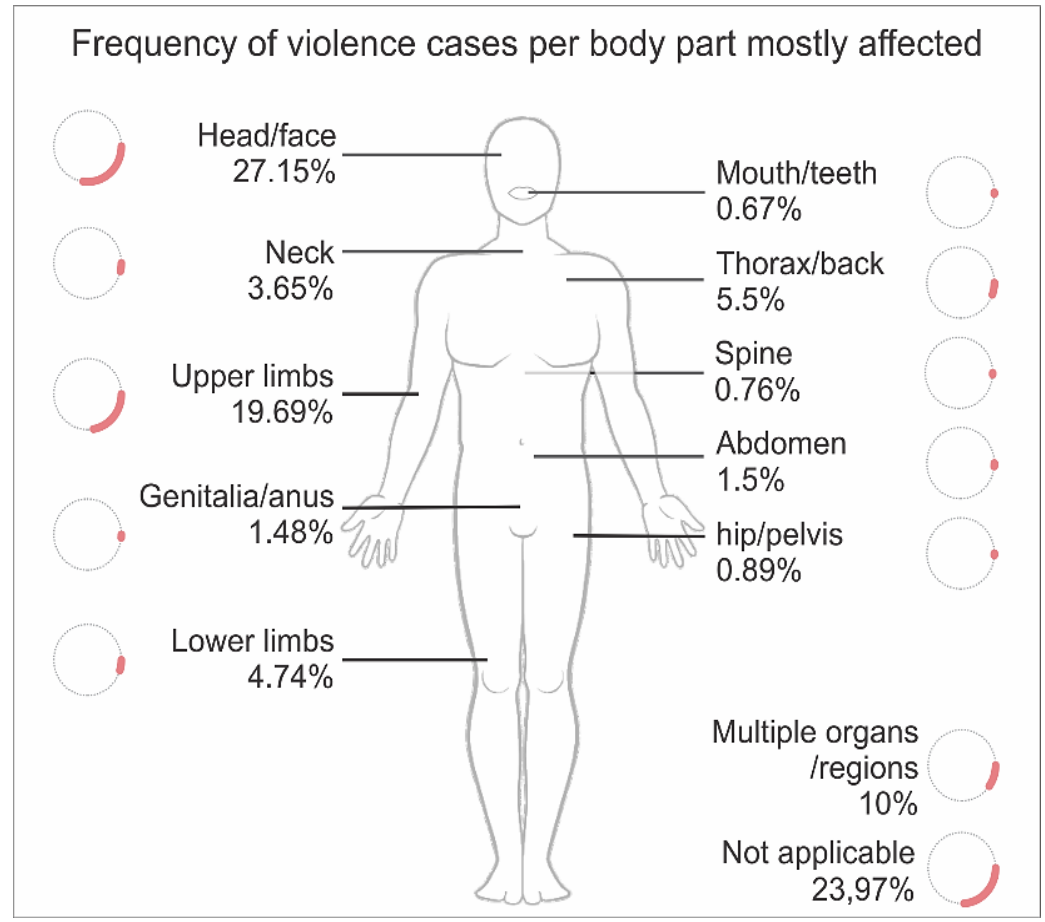

Figure 3. Distribution of violence against the elderly cases according to the body part most affected. Data from SINAN between 2007 and 2017

Table 1. Distribution of the violence against the elderly cases according to the body part mostly affected, number of involved, gender of the assaulted and alcohol use suspicion. Data from SINAN between 2007 and 2017

\begin{tabular}{|c|c|c|c|c|}
\hline Variables & Number of cases & Frequency $(\%)$ & Number of deaths & Frequency $(\%)$ \\
\hline \multicolumn{5}{|l|}{ Body part } \\
\hline Head/face & 1249 & 27.15 & 49 & 26.92 \\
\hline Neck & 168 & 3.95 & 48 & 26.37 \\
\hline Mouth/teeth & 31 & 0.67 & & \\
\hline Spine/marrow & 35 & 0.76 & 1 & 0.55 \\
\hline Chest/back & 253 & 5.50 & 14 & 7.69 \\
\hline Abdomen & 69 & 1.50 & 3 & 1.65 \\
\hline Hip/pelvis & 41 & 0.89 & 2 & 1.10 \\
\hline Upper limbs & 906 & 19.69 & 5 & 2.75 \\
\hline Lower limbs & 218 & 4.74 & 3 & 1.65 \\
\hline Genitals/anus & 68 & 1.48 & 40 & 21.98 \\
\hline Multiples Organs/regions & 460 & 10 & 17 & 9.34 \\
\hline Presence of DNA & 1103 & 23.97 & & \\
\hline \multicolumn{5}{|l|}{ Number of involved } \\
\hline One & 9121 & 60.46 & 137 & 70.62 \\
\hline Two or more & 4485 & 29.73 & 28 & 14.43 \\
\hline Ignored/Blank & 1480 & 9.81 & 29 & 14.95 \\
\hline \multicolumn{5}{|l|}{ Gender of the assaulted } \\
\hline Male & 6881 & 45.61 & 139 & 71.65 \\
\hline
\end{tabular}




\begin{tabular}{lcccc} 
Female & 8204 & 54.38 & 55 & 28.35 \\
Ignored/Blank & 1 & 0.01 & 0 & 0 \\
Alcohol use suspicion & & & & 12.89 \\
Yes & 4314 & 28.60 & 25 & 44.33 \\
No & 6471 & 42.89 & 86 & 42.78 \\
Ignored/Blank & 4301 & 28.51 & 83 & \\
\hline
\end{tabular}

Additionally, the data collected from SINAN point that the more affected races/ethnicities were white subjects $(43.88 \%)$, followed by multiracial $(33.06 \%)$. Besides this, when the comparison is made with the death numbers, the white elderly represent $59.28 \%$ of the victims (Table 2).

Table 2. Distribution of violence against the elderly cases according to the race, marital status, place of occurrence, and if it occurred in a shelter. Data from SINAM between 2007 and 2017

\begin{tabular}{|c|c|c|c|c|}
\hline Variables & Number of cases & Frequency $(\%)$ & Number of deaths & Frequency $(\%)$ \\
\hline \multicolumn{5}{|l|}{ Race/Ethnicity } \\
\hline White & 6620 & 43.88 & 115 & 59.28 \\
\hline Black & 1640 & 10.87 & 12 & 6.19 \\
\hline Yellow & 104 & 0.69 & 2 & 1.03 \\
\hline Multiracial & 4988 & 33.06 & 56 & 28.87 \\
\hline Indigenes & 51 & 0.34 & 0 & 0 \\
\hline Ignored/Blank & 1683 & 11.16 & 9 & 4.64 \\
\hline \multicolumn{5}{|l|}{ Marital status } \\
\hline Single & 1905 & 12.63 & 25 & 12.89 \\
\hline Married/consensual union & 5735 & 38.02 & 96 & 49.48 \\
\hline Widow/widower & 3803 & 25.21 & 29 & 14.95 \\
\hline Divorced & 1119 & 7.42 & 17 & 8.76 \\
\hline DNA & 262 & 1.67 & 3 & 1.55 \\
\hline Ignored/Blank & 2272 & 15.06 & 24 & 12.37 \\
\hline \multicolumn{5}{|l|}{ Place of occurrence } \\
\hline Home & 11285 & 80.42 & 132 & 73.33 \\
\hline House Shared & 108 & 0.77 & 4 & 2.22 \\
\hline School & 32 & 0.23 & 0 & 0 \\
\hline Place of sportive activities & 20 & 0.14 & & \\
\hline Bar or similar & 318 & 2.27 & 5 & 2.78 \\
\hline Public places & 1692 & 12.06 & 27 & 15 \\
\hline Commerce/services & 156 & 1.11 & 2 & 1.11 \\
\hline Industries/construction & 9 & 0.06 & & \\
\hline Others & 412 & 2.94 & 10 & 5.56 \\
\hline \multicolumn{5}{|l|}{ Shelter places } \\
\hline Yes & 37 & 0.25 & 1 & 0.52 \\
\hline No & 4019 & 26.64 & 161 & 82.99 \\
\hline Ignored/Blank & 11030 & 73.11 & 32 & 16.49 \\
\hline
\end{tabular}

In addition, as seen in Table 2, the majority of the acts of violence were suffered by married individuals (38.02\%) or widowers and widows $(25.21 \%)$, and most of those acts of violence occurred inside their own residence. Another factor that draws attention is the fact that most of the aggressors are their offspring, with a percentage of $26.87 \%$ of the cases, and that unknowns are responsible for $12.89 \%$ of the violence cases that led to death (Table 3). 
Table 3. Distribution of violence against the elderly cases according to sex and relationship of the author. Data from SINAN between 2007 and 2017

\begin{tabular}{|c|c|c|c|c|}
\hline Variables & Number of cases & Frequency $(\%)$ & Number of deaths & Frequency $(\%)$ \\
\hline \multicolumn{5}{|l|}{ Gender of the author } \\
\hline Male & 9201 & 60.99 & 128 & 65.98 \\
\hline Female & 3326 & 22.05 & 34 & 17.53 \\
\hline Both & 884 & 5.86 & 1 & 0.52 \\
\hline Ignored/Blank & 1675 & 11.10 & 31 & 15.98 \\
\hline \multicolumn{5}{|l|}{ Relationship - Father } \\
\hline Yes & 127 & 0.84 & 1 & 0.52 \\
\hline No & 13034 & 86.40 & 155 & 79.90 \\
\hline Ignored/Blank & 1925 & 12.76 & 38 & 19.59 \\
\hline \multicolumn{5}{|c|}{ Relationship - Mother } \\
\hline Yes & 177 & 1.17 & & \\
\hline No & 12993 & 86.13 & 156 & 80.41 \\
\hline Ignored/Blank & 1916 & 12.70 & 38 & 19.59 \\
\hline \multicolumn{5}{|c|}{ Relationship - Partner } \\
\hline Yes & 1525 & 10.11 & 8 & 4.12 \\
\hline No & 11698 & 77.54 & 149 & 76.80 \\
\hline Ignored/Blank & 1863 & 12.35 & 37 & 19.07 \\
\hline \multicolumn{5}{|c|}{ Relationship - Ex-partner } \\
\hline Yes & 190 & 1.26 & 2 & 1.03 \\
\hline No & 12963 & 85.93 & 154 & 79.38 \\
\hline Ignored/Blank & 1933 & 12.81 & 38 & 19.59 \\
\hline \multicolumn{5}{|c|}{ Relationship - Valentine } \\
\hline Yes & 102 & 0.68 & 1 & 0.52 \\
\hline No & 13036 & 86.41 & 154 & 79.38 \\
\hline Ignored/Blank & 1948 & 12.91 & 39 & 20.10 \\
\hline \multicolumn{5}{|c|}{ Relationship - Son/daughter } \\
\hline Yes & 4054 & 26.87 & 10 & 5.15 \\
\hline No & 9327 & 61.83 & 146 & 75.26 \\
\hline Ignored/Blank & 1705 & 11.30 & 38 & 19.59 \\
\hline \multicolumn{5}{|c|}{ Relationship - Unknown } \\
\hline Ignored/Blank & 1848 & 12.25 & 38 & 19.59 \\
\hline Yes & 2035 & 13.49 & 25 & 12.89 \\
\hline No & 11203 & 74.26 & 131 & 67.53 \\
\hline \multicolumn{5}{|c|}{ Relationship - Caregiver } \\
\hline Yes & 272 & 13.49 & 0 & 0 \\
\hline No & 12887 & 74.26 & 154 & 79.38 \\
\hline Ignored/Blank & 1927 & 12.25 & 40 & 20.62 \\
\hline
\end{tabular}

From the data obtained in Table 4, was verified that the main cases of violence against the elderly are physical (71.24\%), psychological/moral (33.76\%) and neglect and abandonment (15.8\%). Consonant to that, $88.66 \%$ of the violence cases that resulted in death were due to physical violence suffered by the elderly. 
Table 4. Distribution of the violence against the elderly cases according to the type of violence practiced. Data from SINAN between 2007 and 2017

\begin{tabular}{|c|c|c|c|c|}
\hline Variables & Number of cases & Frequency $(\%)$ & Number of deaths & Frequency $(\%)$ \\
\hline \multicolumn{5}{|l|}{ Physical violence } \\
\hline Yes & 10747 & 71.24 & 172 & 88.66 \\
\hline No & 3912 & 25.93 & 17 & 8.76 \\
\hline Ignored/Blank & 427 & 2.83 & 5 & 2.58 \\
\hline \multicolumn{5}{|l|}{ Moral/Psico violence } \\
\hline Yes & 5093 & 33.76 & 19 & 9.79 \\
\hline No & 9106 & 60.36 & 156 & 80.41 \\
\hline Ignored/Blank & 887 & 5.88 & 19 & 9.79 \\
\hline \multicolumn{5}{|l|}{ Torture } \\
\hline Yes & 606 & 4.02 & 12 & 6.19 \\
\hline No & 13419 & 88.95 & 163 & 84.02 \\
\hline Ignored/Blank & 1061 & 7.03 & 19 & 9.79 \\
\hline \multicolumn{5}{|l|}{ Sexual violence } \\
\hline Yes & 362 & 2.40 & 1 & 0.52 \\
\hline No & 13708 & 90.87 & 174 & 89.69 \\
\hline Ignored/Blank & 1016 & 6.73 & 19 & 9.79 \\
\hline \multicolumn{5}{|c|}{ Financial/Economic violence } \\
\hline Yes & 961 & 6.37 & 4 & 2.06 \\
\hline No & 13103 & 86.86 & 170 & 87.63 \\
\hline Ignored/Blank & 1022 & 6.77 & 20 & 10.31 \\
\hline \multicolumn{5}{|l|}{ Neglected/abandoned } \\
\hline Yes & 2383 & 15.80 & 6 & 3.09 \\
\hline No & 11864 & 78.64 & 169 & 87.11 \\
\hline Ignored/Blank & 839 & 5.56 & 19 & 9.79 \\
\hline
\end{tabular}

\section{Discussion}

The data collected in this study highlight some points that deserve thorough qualitative attention and discussion as a mean of understanding the violence against the elderly scenery in the state. Thus, we started from the perspective that this violence emerges from political, economic and cultural factors that exist in everyday relationships [14].

\subsection{About the Violence Consummated by the Offspring}

The majority of the elderly affected by the violence contemplated by this study corresponds to the feminine gender (54.38\%), although this difference is of inverse significance, considering that the general feminine elderly population is $61.4 \%$ [13] of the total, leading to a higher chance of men suffering this kind of violence in his life. On the other side, the aggressors are constituted mostly by men (60.99\%). Those data may lead to an immediate thought that the violence occurs between partners, as a reflex of the patriarchal that surround us. But when we connected this data to the information that the main aggressors are the offspring (47\%), the need to amplify the interpretation arose. Besides that, it is important to highlight the data shown in Table 4, that the physical violence prevails with the occurrence twice as high as the psychosocial/moral, the second more frequent type.

When merging the three information, is possible to infer that the aged that suffer those aggressions is that who is financially and physically dependent on his offspring, who opt not to omit basic care - like shelter, food, and hygiene as those are rights guaranteed by the statute of the elder [8] and when not fulfilled characterize a crime and, sometimes, torture. Hence, it is believed that this violence is stimulated by negative feelings, as revenge by the treatment that the aggressor received in his childhood, as physical, psychosocial, and even sexual violence. Papalia, Olds, and Feldman punctuated that the success in relation to the coexistence of elders that live with their offspring depends mainly on the quality of the relationship that existed in the past and on the capacity of both generations communicate in a plain and honest manner [15]. With this analysis, we can understand that the violence to the elder is not limited by a punctual occasion but can be a reflex of all of the decisions and interpersonal and familial relations during the whole life of the subject that reaches an advanced age. In this case, it would be fundamental the constant accompaniment of the routine of the elder by a social worker, as the development of public policies that reduce the 
domestic violence between any relatives, because its effects and consequences may reverberate along the whole life inside the home.

\subsection{Putting the Violence against the Elderly in Context}

The results gathered shows that the biggest segment of the aggressions against the elderly of both sexes is mainly done by one person (Table 1). Based on that, and on the data about the distribution of the violence cases against the elderly considering the sex and the relationship of the aggressor (Table 3: SINAN data from 2007 to 2017), it was possible to verify that a big part of the aggressor is really close to the victims, and possibly, have a lot of influence under the victim, either by the daily care or by having the controlling the particular assets. Because the researches point that a considerable amount of the aggressions comes from a close relative or a caregiver [16-18].

In the familiar context, the aggressions against the elderly are made, mainly, by the offspring or partner, making them responsible for two-thirds of the maltreatment, and domestic negligence [16]. It is understood as domestic violence, the actions or omissions that harm de welfare, physical and psychological integrity, and freedom of a family member. They are types of violence that can be done either inside or outside the home, by any relative that holds a power relationship with the victim $[17,18]$.

According to Menezes [19], MS [20], and other international researchers as Anetzberger et al., [21], Ortmann et al. [22], and Wolf [23] highlighted the existence of a profile to the family aggressor, and that, generally, are sons, followed by daughters, daughters in law, sons in law, and, lastly, partners. The aggressor profile is also linked to the risk situation that the victims live, such as the aggressor and the victim live in the same house, the offspring being financially dependent on the elderly parents or the parents depending on their sons/daughters, the abuse of substances such as alcohol and other drugs by the aggressor, the lack of a strong familial connection, the existence of a uncomfortable ambient, lack of communication or affection, isolation between the family, the elderly is or were an aggressive person, the existence of a violence history in the family, caregivers already been victims of domestic violence, suffering from depression or any other mental or psychiatric condition.

Some researchers seek to demystify the idea that caretakers are the biggest aggressors, and the situations of violence and negligence would tend to increase in the case of the more dependent elderly. Kleins-chmidt [24] and Reay and Browne [25] highlight that this situation is really sensitive, and stressful at the same time, but it only tends to results in violence when the caretakers socially isolated themselves, when they suffer from a psychiatric disorder, when there is not a strong bond between them and the elderly, and, even, when they had experienced episodes of violence on their life.

The violence characterized as domestic is not only classified as violence practiced by the family because it involves all the people that attend to the same domestic place and that are, in any way, linked, with or without kinship ties. The caregivers that care for the elderly, in their home, shelter or institutions of care, are directly linked to this type of violence, because the term "domestic" also includes people that attend to the familiar environment, as employees, aggregates and sporadic visitors $[17,26]$.

To some authors, the perpetuation of the domestic violence is linked to the existence of a big number of elderly dependent of their family, thanks to the increase of the life expectancy that comes from the population-ageing. Nonetheless, it is noticeable that in the last decades, the family has been through fast structural changes as divorces, new marriages, financial instability, changes on the life standard, national and international migrations, and other factors that has collaborated to the changes on the familiar structure, the increase on the stress conditions, and deterioration of the quality of the familiar relationships [27].

Caldas [28] affirms that, although we have a National Policy for Elderly Health, in Brazil there is no program made specifically for this population that depends on someone else, and it would directly affect issues that define the caregiver function as an exclusive family task. This way, it is possible to assume that the family that proposes to take care of a senior highly dependent is susceptible to suffer from constant episodes of financial pressure, functions overload, physical and psychological wear among other points that might unleash maltreatment and negligence situations against the elderly at home.

It is inevitable to highlight the importance of the elderly to need people who are qualified to help them also that necessary, but not always the professionals are qualified enough to deal directly with senior, especially because these people need extra care and protection. The supervision and better qualification of healthcare professionals, like the caregivers, would contribute significantly to identify the maltreatment caused by other people, in health institutions, home and in the streets.

Another important point to be highlighted refers to the marginalization of elderly that is still very present at the social context, being considered a contributing factor for the permanency and the grievance of the violence against elderly. For Souza, Freitas, and Queiroz [29], the violence background enforces many obstacles to the safe and 
appropriated aging process, so it is really important the participation of all the governmental levels at the construction of preventive strategies against the familiar violence that preserves the cares with the elderly in an integrated way, especially for those who depend the most, who are fragilized and victims of maltreatment inside the family core or at the main permanence institution. This kind of violence includes not only the senior victimized but also his family, the caregivers and the healthcare system which will also take care of the elderly and the consequences brought by this violence to the society [30].

Herrera [31] highlights the invisibility relationship established with the elderly by their relatives that don't know and even ignore the social, political and personal participation that senior still have in society, disrespecting his individuality, capability of making decisions, participation, and exigence of his rights. The procedure of getting old with respect and dignity should be a natural way, ensuring the active participation of these seniors in society, but many people make sure it becomes a social excluding process, with infantile treatment and renegade of the person, what harms their life quality.

\section{Conclusion}

In front of the analysis of Sinan database, is possible to conclude that in the state of Minas Gerais the percentage of elderly women that suffer aggression is bigger than the men. Furthermore, most of the aggressions are made by male people that live with or have some close relationship grade with the victim as son, husband, in-laws, and caretakers. Also, physical aggression is the most recurrent. In this scenario of familial violence, it is possible that it has been motivated by a relationship full of violence and negative feelings. The lack of public policy made exclusively for the elderly make the familiars the only responsible one for the care and wellbeing of the seniors, which may cause negligence and bad care situations. Since the creation of the Senior Citizens' Statute, the State became responsible for this portion of the population, so the implementation of this kind of care must be considered as important as the rest of the agenda of Brazilian public healthcare.

This study shows that is necessary to improve the qualification of the healthcare professionals, such as the caregivers and the ones who serve these elderly and their families. It is also important to provide attention and orientation to familiar cores where the violence is present because the child that suffers violence might become the aggressor.

\section{Declaration of Competing Interest}

The authors declare that they have no known competing financial interests or personal relationships that could have appeared to influence the work reported in this paper.

\section{Ethical Approval}

All procedures performed in studies involving human participants were in accordance with the ethical standards of the institutional and/or national research committee and with the 1964 Helsinki declaration and its later amendments or comparable ethical standards.

\section{References}

[1] Miranda, G. M. D., Mendes, A. da C. G., \& Silva, A. L. A. da. (2016). Population aging in Brazil: current and future social challenges and consequences. Revista Brasileira de Geriatria e Gerontologia, 19(3), 507-519. doi:10.1590/180998232016019.150140

[2] Souza, M. de F. M. de, Malta, D. C., França, E. B., \& Barreto, M. L. (2018). Transição da saúde e da doença no Brasil e nas Unidades Federadas durante os 30 anos do Sistema Único de Saúde. Ciência \& Saúde Coletiva, 23(6), 1737-1750. doi:10.1590/1413-81232018236.04822018.

[3] Vasconcelos, A. M. N., \& Gomes, M. M. F. (2012). Transição demográfica: a experiência brasileira. Epidemiologia e Serviços de Saúde, 21(4), 539-548. doi:10.5123/s1679-49742012000400003.

[4] Krug, E. G., Mercy, J. A., Dahlberg, L. L., \& Zwi, A. B. (2002). The world report on violence and health. The Lancet, 360(9339), 1083-1088. doi:10.1016/s0140-6736(02)11133-0.

[5] Queiroz, Z. P. V. D., Lemos, N. D. F. D., \& Ramos, L. R. (2010). Fatores potencialmente associados à negligência doméstica entre idosos atendidos em programa de assistência domiciliar. Ciência \& Saúde Coletiva, 15, 2815-2824.

[6] Lei n. 8.842, de 04 de janeiro de 1994. Dispõe sobre a política nacional do idoso, cria o Conselho Nacional do Idoso e dá outras providências. Available online: http://www.planalto.gov.br/ccivil_03/leis/L8842.htm.

[7] Decreto n. 1.948, de 03 de julho de 1996. Regulamenta a Lei ${ }^{\circ} 8.842$, de 4 de janeiro de 1994, que dispõe sobre a Política Nacional do Idoso, e dá outras providências. Available online: http://www.planalto.gov.br/ccivil_03/decreto/D1948.htm. 
[8] Lei $\mathrm{n}^{\circ}$ 10.741, de 01 de out. de 2003. Dispõe sobre o Estatuto do Idoso e dá outras providências. Available online: http://www.planalto.gov.br/ccivil_03/leis/2003/L10.741.htm.

[9] Brasil, Ministério da Saúde (2017). VIVA: Vigilância de Violências e Acidentes - 2013 e 2014. Secretaria de Vigilância em Saúde, Brasília, DF. Available online: http://www.saude.gov.br/bvs.

[10] Brito, L.S.F. (1993). Sistema de informações de agravos de notificação - Sinan: Anais do Seminário de Vigilância Epidemiológica. Fundação Nacional de Saúde, 145-146.

[11] Minas Gerais. In: Governo do Estado de Minas Gerais. Localização Geográfica. Available online: https://www.mg.gov.br/conheca-minas/geografia. (accessed on March 2019).

[12] Brasil. In: IBGE Instituto Brasileiro de Geografia e Estatística. Brasil em Síntese - IBGE. 2019. Available online: https://cidades.ibge.gov.br/brasil/mg/panorama. (accessed on March 2019).

[13] Da população do Brasil, IBGE Projeção. por sexo e idade 1980-2050, Revisão 2008. Rio de Janeiro: IBGE, 2008.

[14] Rocha, R. da C., Côrtes, M. da C. J. W., Dias, E. C., \& Gontijo, E. D. (2018). Violência velada e revelada contra idosos em Minas Gerais-Brasil: análise de denúncias e notificações. Saúde Em Debate, 42(spe4), 81-94. doi:10.1590/010311042018 s406.

[15] Papalia, D. E., Olds, S. W., Feldman, R. D. (2007). Human development. 10th ed. New York, NY, US: McGraw-Hill.

[16] Chavez, N., (2002). Violence against Elderly. Available online: http:/www.health.org/referrals/resguides. asp. (accessed on October 2018)

[17] Day, V. P., Telles, L. E. de B., Zoratto, P. H., Azambuja, M. R. F. de, Machado, D. A., Silveira, M. B., ... Blank, P. (2003). Violência doméstica e suas diferentes manifestações. Revista de Psiquiatria Do Rio Grande Do Sul, 25(suppl 1), 9-21. doi:10.1590/s0101-81082003000400003.

[18] Camargo, C. L. D., \& Buralli, K. O. (1998). Violência familiar contra crianças e adolescentes. In Violência familiar contra crianças e adolescentes (pp. 169-169).

[18] Menezes, M. R. (1999). Da violência revelada à violência silenciada: um estudo etnográfico sobre a violência doméstica contra o idoso (Tese de doutorado). Faculdade de Enfermagem, Universidade de São Paulo, São Paulo, SP, Brasil. Available online: https://bdpi.usp.br/single.php?_id=001067004.

[20] Ministério da Saúde. (2001). Política nacional de redução da morbimortalidade por acidentes e violências.

[21] Anetzberger, G. J., Korbin, J. E., \& Austin, C. (1994). Alcoholism and Elder Abuse. Journal of Interpersonal Violence, 9(2), 184-193. doi:10.1177/088626094009002003.

[22] Ortmann, C., Fechner, G., Bajanowski, T., \& Brinkmann, B. (2001). Fatal neglect of the elderly. International Journal of Legal Medicine, 114(3), 191-193. doi:10.1007/s004140000173.

[23] Wolf, R. S. (1995). Maltrato en ancianos. Atención de los ancianos: un desafio para los noventa, 35-42.

[24] Kleinschmidt, K. C. (1997). Elder Abuse: A Review. Annals of Emergency Medicine, 30(4), 463-472. doi:10.1016/s01960644(97)70006-4.

[25] Reay, A. M. C., \& Browne, K. D. (2001). Risk factor characteristics in carers who physically abuse or neglect their elderly dependants. Aging \& Mental Health, 5(1), 56-62. doi:10.1080/13607860020020654.

[26] Araújo, M. de F. (2002). Violência e abuso sexual na família. Psicologia Em Estudo, 7(2), 3-11. doi:10.1590/s141373722002000200002 .

[27] Karsch, U. M. (2003). Idosos dependentes: famílias e cuidadores. Cadernos de Saúde Pública, 19, 861-866.

[28] Caldas, C. P. (2003). Envelhecimento com dependência: responsabilidades e demandas da família. Cadernos de Saúde Pública, $19,733-781$.

[29] de Souza, J. A. V., de Freitas, M. C., \& de Queiroz, T. A. (2007). Violência contra os idosos: análise documental. Revista Brasileira de Enfermagem, 60(3), 268-272.

[30] Sanches, A. P. R. A., Lebrão, M. L., Duarte, Y. A. D. O. (2008). Violência contra idosos: uma questão nova? Saúde e Sociedade, 17, 90-100.

[31] Herrera, A. M. M. (2004). Consideraciones sobre maltrato y violência en la vejez: a la luz de calidad de vida. Grupo Interdisciplinario sobre Envejecimiento, Universidad Nacional de Colombia. 